\title{
Optimalisasi Pemanfaatan Daun Kelor Sebagai Produk Olahan Bernilai Gizi dan Bernilai Ekonomi Tinggi
}

\author{
Astrid Maharani ${ }^{1 *}$, Retno Murwanti ${ }^{2}$ \\ ${ }^{1,2}$ Program Studi Akuntansi, Fakultas Ekonomi, Universitas Muhammadiyah Jember \\ ${ }^{1}$ astrid.maharani@unmuhjember.ac.id, ${ }^{2}$ retnomurwanti@unmuhjember.ac.id
}

\begin{abstract}
Moringa oleifera is the one of familiar plants in Harjomulyo Village. The one factor of the number moringa plants in Harjomulyo Village because it's too easy to grow in tropical climates, have high rainfall and are resistant to dry seasons. The problem of Harjomulyo Village is a lack of knowledge related to nutritional value and high economic value related to moringa plants which are widely available in Harjomulyo Village. The aim of this service is to educate the Moringa plant into processed nutritious food that has high economic value for the people of Harjomulyo Village. In solving the problem, it is carried out by extension methods and discussions about the benefits of moringa plants for health and fulfillment nutrition for family, technical counseling on the process of moringa sticks, packaging of moringa sticks, and business and marketing analysis of moringa sticks.
\end{abstract}

Keywords : moringa oleifera, nutritional value, economic value

\begin{abstract}
Abstrak
Tanaman kelor atau moringa oleifera merupakan salah satu tanaman yang mudah di temui di Desa Harjomulyo. Faktor pendukung banyaknya tanaman ini di Desa Harjomulyo adalah tanaman ini mudah tumbuh di tempat yang beriklim tropis, memiliki curah hujan tinggi dan dengan daya tahan terhadap musim kering. Permasalahan yang dihadapi adalah kurangnya pengetahuan terkait nilai gizi dan nilai ekonomi tinggi terkait tanaman kelor yang banyak ada di Desa Harjomulyo. Tujuan dilakukannya pengabdian ini adalah mengedukasi tanaman kelor menjadi olahan makanan bergizi yang mempunyai nilai ekonmi yang tinggi bagi masyarakat Desa Harjomulyo. Dalam pemecahan masalah dilakukan dengan metode penyuluhan dan diskusi tentang manfaat tanaman kelor bagi kesehatan dan pemenuhan gizi keluarga, penyuluhan teknis tentang pembuatan stik kelor, pengemasan stik kelor, dan analisis usaha dan pemasaran dari stik kelor.
\end{abstract}

Kata Kunci: tanaman kelor, nilai gizi, nilai ekonomi

*Penulis Korespondensi : Astrid Maharani

\section{PENDAHULUAN}

Dalam upaya untuk meningkatkan kemandirian masyarakat, yang memungkinkan masyarakat mampu membangun diri dan lingkungannya berdasarkan potensi, kebutuhan aspirasi dan kewenangan yang ada pada masyarakat sendiri, maka sangat diperlukan salah satu pilar dalam penguatan ekonomi daerah secara spesifik, dan hal itu haruslah dimulai dari lingkungan terkecil dari komunitas masyarakat yaitu Desa, Kelompok Pemberdayaan Kesejahteraan Keluarga
(PKK), kelompok Dasa Wisma. Hal ini haruslah difasilitasi oleh pemerintah dan seluruh stakeholders pemberdayaan masyarakat, termasuk perguruan tinggi.

Daun kelor yang tadinya hanya dikonsumsi sebagai sayuran saja kini dapat dijadikan sebagai produk yang memiliki nilai tambah. Stik Daun Kelor ini termasuk olahan yang sangat mudah sehingga masyarakat dapat mandiri mengembangkan produk tersebut dan aman untuk dikonsumsi sehari-hari. Ide ini berawal dari keprihatinan melihat banyaknya 
tumbuhan kelor yang ada dilahan sekitar lingkungan kita yang dibiarkan tumbuh rimbun dan dijadikan pakan ternak begitu saja. Sehingga kami mencari ide bagaiamana caranya agar tumbuhan tersebut bisa dimanfaatkan warga setempat menjadi olahan yang lebih memiliki nilai tambah.

Halaman rumah/pekarangan merupakan lahan yang potensial untuk dikembangkan menjadi lahan pertanian yang produktif terutama untuk pemenuhan kebutuhan pangan yang bergizi bagi pemiliknya. Termasuk melimpahnya pohon kelor yang ada di Desa Harjomulyo, hal ini karena setiap halaman rumah yang ada di Desa Harjomulyo pasti terdapat pohon kelor. Kesegaran makanan yang tersedia seperti sayur (dalam hal ini kelor) mengalami perubahan bentuk dalam hasil pengolahannya untuk meningkatkan nilai ekonomisnya. Untuk mengatasi hal tersebut, terdapat sebuah inovasi pengolahan pangan yang dapat mempertahankan masa simpan sayur kelor, tanpa mengurangi manfaatnya, sekaligus menambah nilai ekonomisnya.

Upaya pemanfaatan kelor dengan nama latin moringa oleifera menjadi olahan aneka olahan makanan yang sehat dan bergizi dilakukan oleh ibu-ibu Kelompok Pemberdayaan Kesejahteraan Keluarga Desa Harjomulyo, Kecamatan Silo, Kabupaten Jember. Pemanfaatan pekarangan dengan menanam sayuran seperti kelor, bayam, sawi, dan kangkung banyak dilakukan oleh masyarakat di desa Harjomulyo, yang berguna untuk pemenuhan kebutuhan rumah tangga pemiliknya. Diharapkan dengan adanya program pengabdian masyarakat akhirnya akan tercipta suatu kesadaran masyarakat untuk mengembangkan berbagai macam olahan sayuran dari kelor, sehingga bisa menambah nilai ekonomisnya dan berguna meningkatkan perekonomian ibu-ibu pada Kelompok Pemberdayaan Kesejahteraan Keluarga Desa Harjomulyo kala pandemi Covid-19.

\section{METODE}

Metode yang digunakan dalam kegiatan Pengabdian Pada Masyarakat ini yang pertama adalah metode penyululuhan dan diskusi tentang manfaat tanaman kelor bagi kesehatan dan pemenuhan gizi keluarga. Tahapan ini sebagai tahap awal perkenalan tentang seberapa besar nilai gizi yang terkandung dalam tanaman kelor. Proses pengolahan atau pembuatan Stik Kelor pengetahuan baru bagi ibu-ibu anggota dan pengurus PKK Desa Harjomulyo. Sebelumnya, ibu-ibu rumah tangga belum tahu bagaimana cara mengolah kelor menjadi olahan makanan lain, karena selama ini ibu-ibu Desa Harjomulyo hanya mengolah kelor menjadi sayur saja. Penyuluh juga menjelaskan kelebihan Kelebihan mengolah kelor menjadi bahan pangan yang lain, serta sebagai alternatif lapangan usaha yang cukup prospektif untuk dikembangkan di masa mendatang.

Tujuannya ialah meningkatkan kesadaran dan minat akan pemanfaatan olahan kelor untuk menambah pengetahuan peserta seputar pembuatan Stik Kelor, dan pengetahuan seputar kewirausahaan. Tim akan memberikan kesempatan peserta untuk tanya jawab tentang materi yang disampaikan. Metode kedua yakni metode teknis tentang pembuatan Stik Kelor. Metode ketiga yakni metode teknis tentang pembuatan Stik Kelor. Metode keempat yakni menjelaskan bagaimana analisis usaha dan pemasaran dari Stik Kelor sehingga menjadi produk yang mempunyai daya saing.

\section{HASIL DAN PEMBAHASAN}

Tahap awal perkenalan tentang seberapa besar nilai gizi yang terkandung dalam tanaman kelor. Proses pengolahan atau pembuatan Stik Kelor pengetahuan baru bagi ibu-ibu anggota dan pengurus PKK Desa Harjomulyo. Sebelumnya, ibu-ibu rumah tangga belum tahu bagaimana cara mengolah kelor menjadi olahan makanan lain, karena selama ini ibuibu Desa Harjomulyo hanya mengolah kelor menjadi sayur saja. Tim Pengabdian juga menjelaskan kelebihan tanaman kelor atau moringa oleifera merupakan salah satu tanaman yang mudah di temui di Desa Harjomulyo. Faktor pendukung banyaknya tanaman ini di Desa Harjomulyo adalah tanaman ini mudah tumbuh di tempat yang beriklim tropis, memiliki curah hujan tinggi dan dengan daya tahan 
terhadap musim kering. Daun kelor mengantung vitamin $C$ dan beta karoten (Tahir et al., 2016) selain itu terbukti bahwa daun kelor yang telah melalui metode pengeringan mengandung zat besi dan kalsium (Irwan, 2020). Beberapa kandungan vitamin pada daun kelor membuat tim pengabdian merasa perlu unruk mensosialisasikannya kepada warga Desa Harjomulyo. Dalam upaya pencegahan dan penanggulangan stunting disarankan menggunakan tepung daun kelor tua dengan metode pengeringanpelayuan yang dapat digunakan pada pembuatan PMT Balita dan Ibu hamil (Irwan, 2020).

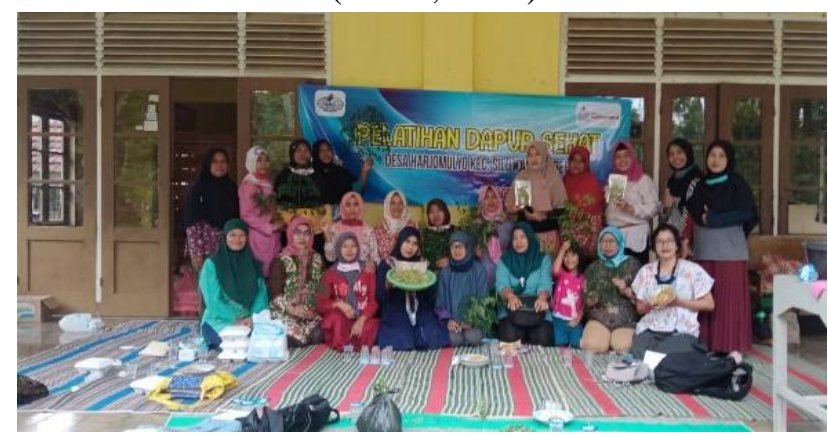

Gambar 1. Penyuluhan dan Diskusi Tentang Manfaat Tanaman Kelor Bagi Kesehatan dan Pemenuhan Gizi Keluarga.

Mengingat banyaknya nilai gizi yang dimiliki oleh daun kelor, maka tim pengabdian mengoptimalisasikannya seiring dengan peningkatan nilai ekonomisnya. Kelebihan mengolah kelor menjadi bahan pangan yang lain, serta sebagai alternatif lapangan usaha yang cukup prospektif untuk dikembangkan di masa mendatang Tujuannya ialah meningkatkan kesadaran dan minat akan pemanfaatan olahan kelor untuk menambah pengetahuan peserta seputar pembuatan Stik Kelor, dan pengetahuan seputar kewirausahaan. Dalam proses pembuatan stik kelor berikut bahan-bahan yang dibutuhkan :

1. Daun kelor 1 ikat

2. Tepung terigu protein sedang $1 \mathrm{~kg}$

3. Mentega $250 \mathrm{gr}$

4. Telur 4 butir

5. Merica $1 / 2 \mathrm{sdm}$

6. Bubuk bawang putih $1 \mathrm{sdm}$

Para peserta penyuluhan teknis dapur sehat pembuatan stik kelor sangat antusias membawa bahan dari kebun mereka masing-masing. Kemudian dilanjutkan dengan proses pembuatan. Proses pembuatan stik kelor adalah dengan memisahkan daun kelor dengan batang, kemudian merebus daun kelor dengan air mendidih hingga daun kelor melunak. Tiriskan daun kelor yang sudah matang tadi. Masukkan bumbu merica dan bubuk bawang ke dalam wadah untuk membuat adonan, tambahkan sedikit demi sedikit air.Kocok telur ke dalam bumbu tadi, tambahkan margarin dan daun kelor yang sudah ditiriskan kemudian aduk hingga merata. Masukkan tepung terigu ke dalam adonan tadi kemudian diuleni hingga kalis, kemudian cetak dengan menggunakan penggiling sesuai selera. Goreng dengan minyak sedang sampai matang dan stik kelor siap dihidangkan/dikemas.

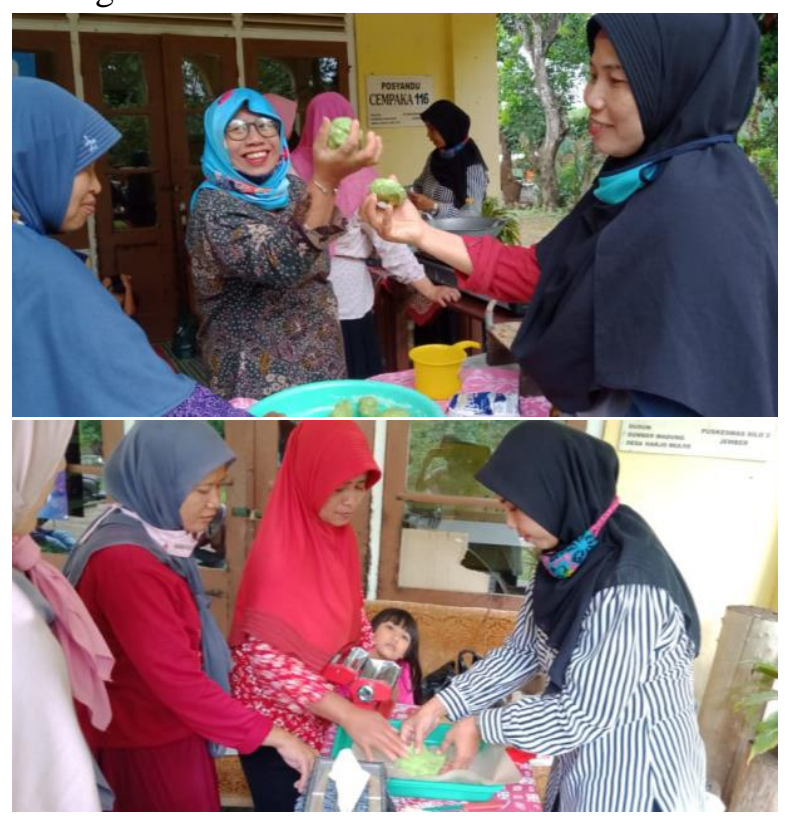

Gambar 2. Penyuluhan Teknis Tentang Pembuatan Stik Kelor

Melakukan pengemasan stik dengan plastik kemasan sehingga plastik tidak mudah robek dan tidak berubah bentuk kerupuk ketika dimasukkan dalam kemasan.Semua anggota kelompok ikut mempraktekkan pembuatan Stik Kelor dan pengemasannya. Tujuan dari tahap ini adalah untuk memaksimalkan produktivitas ibu-ibu PKK Desa Harjomulyo dalam mengembangkan potensi yang dimiliki desa, salah satunya keberadaan daun kelor 
yang banyak tumbuh di desa. Dalam upaya meningkatkan pemasaran pada kedua mitra usaha perlu adanya inovasi yang dilakukan (Maharani \& Sumowo, 2019).

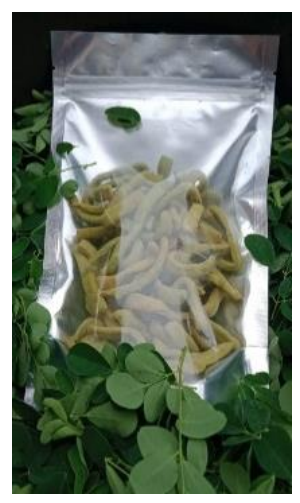

Gambar 3. Pengemasan Stik Kelor Desa Harjomulyo

Selain keberadaannya yang cukup banyak tumbuh di desa, daun kelor memiliki segudang nutrisi dan manfaat yang baik untuk tubuh. Dengan komposisi tepung dan daun kelor sesuai takaran yang telah ditentukan, kemudian mengolahnya menjadi berbagai olahan makanan yang sehat dan bergizi, diantaranya Stik Kelor. Tahap keempat, menjelaskan bagaimana analisis usaha dan pemasaran dari Stik Kelor sehingga menjadi produk yang mempunyai daya saing. Pada kesempatan tersebut tim pengabdian menjelaskan secara mudah cara untuk dapat menghitung analisas kelayakan usaha stik kelor dan perhitungan harga pokok produksi stik kelor secara mudah dengan tujuan adalah memotivasi para peserta yang dominan ibu-ibu bahwa usaha ini layak berjalan dengan Pay Back Period selama 15 minggu atau secara mudah bahwa jangka waktu dari pengembalian modal dlm suatu usaha bisnis adalah dalam kurun waktu 15 bulan.

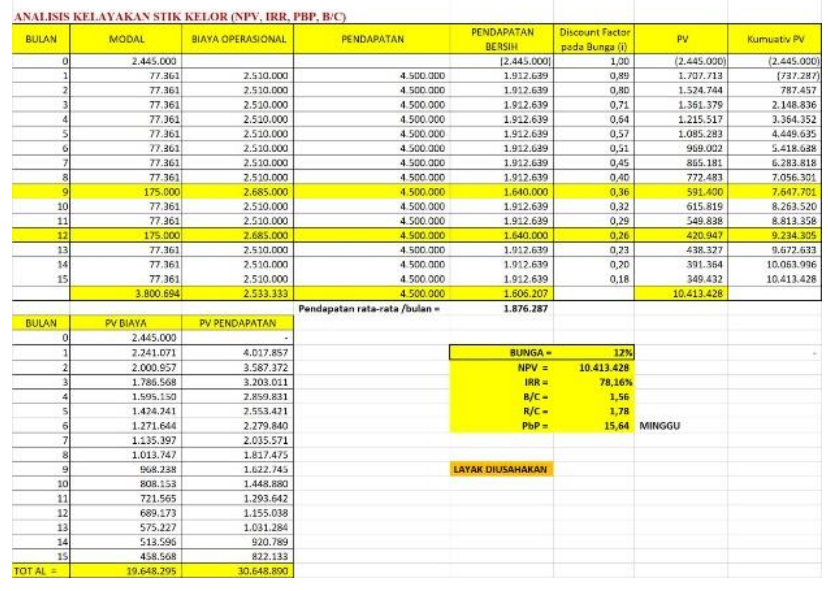

Gambar 4. Perhitungan Analisis Kelayakan Usaha Stik Kelor

\section{KESIMPULAN}

Tanaman kelor atau moringa oleifera merupakan salah satu tanaman yang mudah di temui di Desa Harjomulyo. Faktor pendukung banyaknya tanaman ini di Desa Harjomulyo adalah tanaman ini mudah tumbuh di tempat yang beriklim tropis, memiliki curah hujan tinggi dan dengan daya tahan terhadap musim kering. Permasalahan yang dihadapi adalah kurangnya pengetahuan terkait nilai gizi dan nilai ekonomi tinggi terkait tanaman kelor yang banyak ada di Desa Harjomulyo. Solusi yang ditawarkan adalah bagaimana memanfaatkan melimpahnya tanaman kelor menjadi olahan makanan bergizi yang mempunyai nilai ekonomi yang tinggi.

Dalam pemecahan masalah dilakukan dengan metode:

1. Penyuluhan dan diskusi tentang manfaat tanaman kelor bagi kesehatan dan pemenuhan gizi keluarga.

2. Penyuluhan teknis tentang pembuatan stik kelor.

3. Pengemasan stik kelor.

4. Edukasi analisis usaha dan pemasaran dari stik kelor. 


\section{UCAPAN TERIMA KASIH}

Terima kasih kepada Universitas Muhammadiyah Jember dan LPPM UM Jember yang telah mendukung dosen dalam pengabdian kepada masyarakat ini.

\section{DAFTAR PUSTAKA}

Irwan, Z. (2020). Kandungan Zat Gizi Daun Kelor (Moringa Oleifera) Berdasarkan Metode Pengeringan. Jurnal Kesehatan Manarang, 6(1), 69-77.

Lestari, Ayu Fitri, dan Intan Puspita Sari. (2018). Kelor Sebagai Upaya Pemberdayaan Untuk Meningkatkan Produktivitas Ibu Rumah Tangga. Jurnal Kesmas Untika Luwuk. Vol. 9 (2): 1429-1444.

Maharani, A., \& Sumowo, S. (2019). Inovasi Kue Batik Jember Sebagai Upaya Pengembangan Industri Ekonomi Kreatif Berbasis Kearifan Lokal Jember. CARADDE: Jurnal Pengabdian Kepada Masyarakat, 2(2), 193-202. https://doi.org/10.31960/caradde.v2i2.312

Tahir, M., Hikmah, N., \& Rahmawati, R. (2016). ANALISIS KANDUNGAN VITAMIN C DAN $\beta$ KAROTEN DALAM DAUN KELOR (Moringa oleifra Lam.) DENGAN METODE SPEKTROFOTOMETRI UV-VIS. Jurnal Fitofarmaka Indonesia, 3(1), 135-140. https://doi.org/10.33096/jffi.v3i1.173

Wira'artha, I.C., Negoro, N.P. dan Prasetyo E.N. (2017). Analisis Pengambilan Keputusan dan Strategi Pemasaran di Tingkat Kebutuhan Kelor Indonesia (Kasus Agribisnis: Kelor Madura). Jurnal Sains dan Seni ITS. Vol. 6 (2): D293-D296. 